\title{
Plant growth promoting rhizobacteria as agents in the biocontrol of eucalyptus mini-cutting rot
}

\author{
Reginaldo G. Mafia ${ }^{1}$, Acelino C. Alfenas ${ }^{2}$, Luiz Antônio Maffia ${ }^{2}$, Eraclides M. Ferreira ${ }^{2}$, Daniel Henrique \\ B. Binoti ${ }^{2} \&$ Gizella M. Ventura Mafia ${ }^{3}$
}

${ }^{1}$ Aracruz Celulose S.A., Centro de Pesquisa e Tecnologia, 29197-900, Aracruz, ES, Brazil; ${ }^{2}$ Departamento de Fitopatologia, Universidade Federal de Viçosa, 36570-000, Viçosa, MG, Brazil; ${ }^{3}$ Departamento de Fitotecnia, Universidade Federal de Viçosa, 36570-000, Viçosa, MG, Brazil

Author for correspondence: Acelino C. Alfenas, e-mail: aalfenas@ufv.br

\begin{abstract}
The effectiveness of ten plant growth-promoting rhizobacteria (PGPR) was evaluated for the control of mini-cutting rot of eucalyptus caused by Cylindrocladium candelabrum and Rhizoctonia solani. Inhibition of the "in vitro" mycelial growth of each pathogen differed with PGPR isolate and culture medium evaluated. The most effective group of isolates was FL2 (Pseudomonas sp.), 3918 , S1 and S2 (Bacillus subtilis). Under nursery conditions, isolate $\mathrm{Ca}$ (Pseudomonas fulva) reduced the incidence of mini-cutting rot caused by $C$. candelabrum by $33 \%$ compared to the control, and by $27 \%$ compared to a fungicide treatment (epoxiconazole + pyraclostrobin: 0.4 g. $\mathrm{L}^{-1}$ ). Inoculum density of $C$. candelabrum in the eucalyptus rooting medium decreased significantly beginning at 10 days after the medium was treated with the PGPR isolates. Isolate $\mathrm{Ca}$ was the most efficient in reducing the $C$. candelabrum inoculum at 15 days and in promoting rooting and growth of eucalyptus. For $R$. solani, no differences in disease incidence were found among treatments. Sensitivity of the PGPR isolates to ten fungicides differed widely. Tebuconazole completely inhibited $80 \%$ of the isolates, but epoxiconazole + pyraclostrobin only inhibited the S1 isolate. Isolate S1 was the most sensitive and isolates 3918 and MF2 the most resistant to the majority of active ingredients tested. Isolate $\mathrm{Ca}$ was selected for biological control studies in eucalyptus nursery conditions.
\end{abstract}

Keywords: Eucalyptus, PGPR, Cylindrocladium, Rhizoctonia solani, biological control.

\section{RESUMO}

Rizobactérias promotoras do crescimento de plantas como agentes de biocontrole da podridão de miniestacas de eucalipto Avaliou-se a eficiência de rizobactérias promotoras do crescimento de plantas (PGPR) no controle biológico de Cylindrocladium candelabrum e Rhizoctonia solani, agentes causais da podridão de miniestacas de eucalipto. A inibição "in vitro" do crescimento micelial dos patógenos variou com o isolado de rizobactéria e meio de cultura. De forma geral, os isolados FL2 (Pseudomonas sp.) e 3918, S1 e S2 (Bacillus subtilis) foram os mais eficientes. Sob condições de viveiro, o isolado Ca (Pseudomonas fulva) reduziu a incidência da podridão de miniestacas, causada por $C$. candelabrum, em $33 \%$ em relação à testemunha e $26,7 \%$, em relação à imersão de miniestacas no fungicida (epoxiconazole + pyraclostrobin: 0,4 g. $\mathrm{L}^{-1}$ i.a.). A densidade de inóculo de C. candelabrum no substrato reduziu a partir de 10 dias para todos os isolados de rizobactérias testados. A partir de 15 dias, o isolado Ca foi o mais eficiente na redução da densidade de $C$. candelabrum e na indução do enraizamento de miniestacas e no crescimento de mudas de eucalipto. Para $R$. solani, não houve diferença entre os tratamentos quanto à incidência da doença. Em outro experimento, observou-se ampla variação de resposta dos isolados de rizobactérias aos fungicidas testados. Tebuconazole inibiu completamente o crescimento de $80 \%$ dos isolados testados, enquanto epoxiconazole + pyraclostrobin inibiu apenas o crescimento do isolado S1. O isolado S1 foi o mais sensível e os isolados 3918 e MF2 os mais resistentes para a maioria dos princípios ativos testados. O isolado S1 foi selecionado para estudos de controle biológico em condições de viveiros de eucalipto.

Palavras-chave: Eucalyptus, PGPR, Cylindrocladium, Rhizoctonia solani, controle biológico.

\section{INTRODUCTION}

Cloning of Eucalyptus spp. in Brazil is done mainly by rooting mini-cuttings. High humidity and high temperature favor rooting but also favor development of mini-cutting rot, caused by Cylindrocladium candelabrum Viégas and Rhizoctonia solani J.G. Kühn (Alfenas et al., 2004). Chemical control is not generally effective against cutting rot, in part because the intermittent mist irrigation used for cuttings tends to remove fungicides from the foliage and the active ingredients are not completely absorbed and translocated (Alfenas et al., 2004; Silveira et al., 2003).

Inadequate effectiveness of chemical control and increasing restrictions on fungicide use have given increasing impetus to biological control as an alternative tool for integrated disease management in numerous crops. Plant growth-promoting rhizobacteria (PGPRs) are among many microbes identified as potential biological control 
agents (Kloepper et al., 1989) and were found to be effective in forest tree species (Holl \& Chanway, 1992; Chanway \& Holl, 1993a, 1993b, 1994; Chanway, 1997; Eneback et al., 1998; Shishido \& Chanway, 2000). Colonization of the plant root system by PGPRs was shown to reduce pathogen attack directly through production of antimicrobial substances (e.g. siderophores, $\beta-1,3$ glucanase, chitinases, antibiotics, and cyanidric acid), and through competition for space, nutrients and ecological niches. PGPRs also suppress pathogens indirectly through induction of systemic resistance (Buchenauer, 1998; Cattelan et al., 1999; Kloepper, 1991; Luz, 1993; Whipps, 2001; Kloepper et al., 1992; Van Loon, 1997; Van Loon et al., 1998; Eneback \& Carey, 2000; Ramamoorthy et al., 2001; Viswanathan \& Samiyappan, 2002).

Compatibility of biocontrol agents with other treatments employed in integrated disease management, including fungicide sprays, is important for the agents to be effective. Effectiveness of agents normally depends on the maintenance of sufficient densities and appropriate distributions of agent populations in the host plants, which may be compromised by fungicides and other pesticides. PGPRs compete with communities of other micro-organisms associated with the host plants including those on and in the host tissues and those in the rhizosphere. In the present studies, rhizobacteria isolates were evaluated for biocontrol of mini-cutting rot caused by $C$. candelabrum and by R. solani, and for their sensitivity to two principal fungicides that are used for protecting mini-cuttings.

\section{MATERIALS AND METHODS}

\section{Rhizobacteria isolates and inoculum preparation}

The following ten isolates of rhizobacteria obtained from the rhizosphere of eucalyptus in various regions of Brazil were evaluated (FL2 - Pseudomonas sp.; S1, S2 and 3918 - Bacillus subtilis Cohn, 1872; Ca - Pseudomonas fulva Lizuga \& Komagata 1963; MF2 and MF4 - Pseudomonas sp. Migula, 1894; CIIb Stenotrophomonas maltophilia (Hugh, 1872) Palleroni \& Bradbury, 1993; R1 - Frateuria aurantia Swings et al., 1980; and VC2 - unidentified isolate). They were preselected according to their capacity to promote rooting and increase root biomass (Teixeira et al., 2007; Mafia et al., 2005).

For inoculum preparation, each isolate was grown separately on MB1 agar medium (Kado \& Heskett, 1970) in the dark for $48 \mathrm{~h}$. The colonies were scraped into saline solution $(\mathrm{NaCl} 0.85 \%)$. Density of colony forming units (c.f.u.) in cell suspensions of each isolate was estimated from absorbance measurements at $540 \mathrm{~nm}$ and a standard curve for absorbance and c.f.u./mL. A density of approximately $10^{8}$ c.f.u. $/ \mathrm{mL}$ was used in experiments. The inoculum suspensions were kept in a refrigerator at $5^{\circ} \mathrm{C}$ for a maximum of $2 \mathrm{~h}$ prior to use.

\section{Evaluation of mycelial growth inhibition}

Effectiveness of the rhizobacterial isolates against the growth of $R$. solani and C. candelabrum was examined on MB1 and potato dextrose agar (PDA) media in Petri dishes. For each fungal pathogen, two culture plugs $(5 \mathrm{~mm}$ $\varnothing)$ were positioned at $1.5 \mathrm{~cm}$ from the wall on opposite sides of the medium of each Petri dish. Subsequently, each rhizobacterial isolate was individually streaked across the medium midway between the pathogen plugs. Control dishes were similarly streaked with sterile saline solution. The cultures were incubated at $27^{\circ} \mathrm{C}$ under a 12-h photoperiod. The diameters of the $R$. solani and $C$. candelabrum colonies were measured after 3 and 6 days of incubation, respectively. Percent inhibition of mycelial growth of the pathogens was estimated based on diameters of colonies in the rhizobacteria dishes compared to the control dishes. The experimental design for each pathogen was a factorial with the treatments completely randomized (10 isolates $\times 2$ culture media) and replicated five times.

\section{Efficiency of rhizobacteria isolates in the biocontrol of mini-cutting rot}

The experiment was conducted in a eucalyptus rooting house. The rooting substrate was treated or not treated with a rhizobacterial isolate and infested or not infested with one of the pathogens, all at the same time. The rooting medium consisted of a mixture of carbonized rice husk and vermiculite $(1: 1 \mathrm{v} / \mathrm{v})$, previously enriched with simple super-phosphate $\left(8 \mathrm{~kg} / \mathrm{m}^{3}\right)$, ammonium sulfate $(0.695$ $\left.\mathrm{Kg} / \mathrm{m}^{3}\right)$, potassium chlorate $\left(0.208 \mathrm{Kg} / \mathrm{m}^{3}\right)$, zinc sulfate $\left(0.014 \mathrm{Kg} / \mathrm{m}^{3}\right)$, copper sulfate $\left(0.014 \mathrm{Kg} / \mathrm{m}^{3}\right)$, manganese sulfate $\left(0.014 \mathrm{Kg} / \mathrm{m}^{3}\right)$, and boric acid $\left(0.028 \mathrm{Kg} / \mathrm{m}^{3}\right)$.

To produce inoculum of the pathogens, culture plugs each $5 \mathrm{~mm}$ in diameter were taken from the edge of colonies on PDA, transferred to $125 \mathrm{~mL}$ Erlenmeyer flasks containing $50 \mathrm{~mL}$ of a PDA liquid medium and incubated in the dark for 5 days $(C$. candelabrum) and 7 days ( $R$. solani), respectively. After incubation, the mycelial mass was collected and washed three times with sterilized distilled water under vacuum to remove excess water. The mycelial mat was homogenized in a Polytron ${ }^{\circledR}$ (Brinkman Instruments, Toronto, Canada) at speed 3 for $30 \mathrm{~s}$ and immediately mixed into the rooting medium $(0.2$ $\mathrm{mg}$ fresh mycelium/g substrate). The inoculum suspensions of the rhizobacteria isolates (Ca, FL2 and 3918) were each, adjusted to $10^{8}$ c.f.u. $/ \mathrm{mL}$ and mixed with the rooting substrate of $0.1 \mathrm{~mL} / \mathrm{cc}$ of medium.

Samples of rooting medium treated with the rhizobacteria isolates and infested with the respective pathogens were incubated for five days at $27^{\circ} \mathrm{C}$. Other samples of the medium were infested only with one of the pathogens and kept under the same conditions. Minicuttings of a commercial eucalyptus clone were planted in the treated media and maintained under intermittent mist irrigation. Mini-cuttings, immersed for $3 \mathrm{~min}$ in fungicide solution (epoxyconazole + pyraclostrobin at $0.6 \mathrm{~mL}$ ), were 
used as a fungicide control. Fifty mini-cuttings were used for each treatment, and arranged in a completely randomized factorial design.

The eucalyptus plants were assessed daily for rot symptoms for 25 days after the mini-cuttings were planted. In a destructive harvest at 25 days the plants were assessed for incidence of rooting, dry root biomass, length of root system and disease incidence. To quantify root dry biomass, the aerial part of rooted mini-cuttings was separated from the root system, the medium residue was removed, and the roots were dried at $70^{\circ} \mathrm{C}$ for $48 \mathrm{~h}$. For assessment of disease incidence, mini-cuttings with rot symptoms were collected separately, superficially disinfested in sodium hypochlorite at $1000 \mathrm{ppm}$ of active chlorine for $3 \mathrm{~min}$, washed in sterile water to remove excess $\mathrm{Cl}_{2}$ and then transferred to acidified $(\mathrm{pH}=5.0)$ water-agar $(2 \%)$. The mini-cuttings were incubated in the dark at $27^{\circ} \mathrm{C}$ and examined on a stereoscopic microscope for colonies of $R$. solani after 2 days and for C. candelabrum after 5 days.

\section{Bioassay of pathogen density in infested rooting medium treated with rhizobacteria}

Segments of eucalyptus shoots, each 2.0 to $2.5 \mathrm{~cm}$ long were employed as baits to estimate the relative density of the fungal pathogens in the rooting medium (Sanfuentes et al., 2002; Gonçalves et al., 2001). The baits were buried in the rooting medium of each treatment 5 days after the media were treated with rhizobacteria and infested with C. candelabrum or R. solani, respectively. A completely randomized experimental design was used. For each treatment there were five replicates each of which comprised a gerbox containing the treated medium and 30 baits.

\section{Effect of fungicides on rhizobacteria isolates}

To evaluate the effect of fungicides on the isolates of rhizobacteria, the antibiogram method was used. The rhizobacteria isolates were applied uniformly on MB1 agar medium in Petri dishes. Discs of Whatman filter paper number 2 were soaked in each fungicide (at $2 \mu \mathrm{g}$ a.i. $/ \mathrm{mL}$ ), and dried with forced air for $15 \mathrm{~min}$. Five of the discs were aseptically transferred to the agar medium in each of five replicate dishes per treatment. After incubation at $27^{\circ} \mathrm{C}$ for $48 \mathrm{~h}$ in the dark, the medium was examined for presence $(+)$ or absence (-) of an inhibitory zone of bacterial growth around each disc. A completely randomized experimental design was used with five replicate dishes per treatment.

\section{RESULTS}

Inhibition of mycelial growth of C. candelabrum and $R$. solani differed in relation to the rhizobacterial isolates and culture media tested. Taken together, however, the observations for the two culture media and the two pathogens indicated that the isolates FL2, 3918, S1, and S2 were more effective than the other isolates evaluated.

Isolate S2 inhibited C. candelabrum by 70.7 and
$61.0 \%$ in the assays on PDA and MB1 media, but its effectiveness on PDA did not differ from isolates FL2 and 3918. On the MB1 medium, isolates S1, FL2, 3918 and $\mathrm{VC} 2$, suppressed colony growth of $C$. candelabrum by $61.0,57.5,56.6$, and $56.6 \%$, respectively, which did not differ significantly from the level of suppression obtained for isolate S2 (Figure 1A). When observations for the two culture media are considered, isolate FL2 was the most effective against $R$. solani and inhibited the pathogen by $70.4 \%$ on PDA and $65.7 \%$ on MB1. Isolate S2 inhibited mycelial growth of $R$. solani by $60 \%$ and as effectively as isolate FL2 on the MB1 medium (Figure 1B).

In the biological control experiment in the rooting house, $C$. candelabrum caused higher incidence of minicutting rot than did $R$. solani (Figures 2A-B). For $C$. candelabrum, amendment of the rooting medium with isolate $\mathrm{Ca}$ reduced disease incidence by $33.0 \%$ compared to the control and by $26.7 \%$ compared the treatment of mini-cuttings with the fungicide solution. Rot severity in mini-cuttings treated with isolates FL2 and 3918 or with the fungicide did not differ significantly from that in the control cuttings. None of the treatments significantly affected the incidence of mini-cutting rot caused by $R$. solani, although a trend towards lower disease severity was found for isolate $\mathrm{Ca}$ (Figure 2B).

Rooting was poorer in cuttings placed in rooting medium infested with $C$. candelabrum than in cuttings in the non-infested medium (data not shown). Treatment of the medium with isolate $\mathrm{Ca}$ gave the highest incidence of rooting, which was $132.9 \%$ greater than in the control. For isolate FL2 and the fungicide treatment, rooting incidences were intermediate between those for isolate $\mathrm{Ca}$ and the control (Figure 2C). In rooting medium infested with $R$. solani the incidence of mini-cutting rot was low and the incidence of rooting did not differ among treatments (Figure 2D).

Differences in root system length were observed among treatments for mini-cuttings in rooting medium infested with $C$. candelabrum but not in the Rhizoctonia infested medium (Figures 2E-F). The mean length of root systems was $89.6 \%$ greater for cuttings treated with isolate $\mathrm{Ca}$ than in the untreated controls. Root lengths in other treatments were similar to the control (Figure 2E).

Root biomass of mini-cuttings in the rooting medium treated with isolate $\mathrm{Ca}$, was significantly higher than in the controls for both $C$. candelabrum and $R$. solani (Figures 2G-H). In $R$. solani-infested medium, isolate $\mathrm{Ca}$ promoted root system biomass by $76.5 \%$, and isolate FL2 also increased root system biomass when compared to the control. In the C. candelabrum infested medium isolate $\mathrm{Ca}$ and FL2 significantly increased root biomass (Figure 2G).

In the bioassays the estimated inoculum density of $R$. solani in the artificially-infested media decreased more rapidly and stabilized at a lower level than was found for inoculum of C. candelabrum (Figures 3A-B). Further, no differences in inoculum level were observed 
PDA Medium

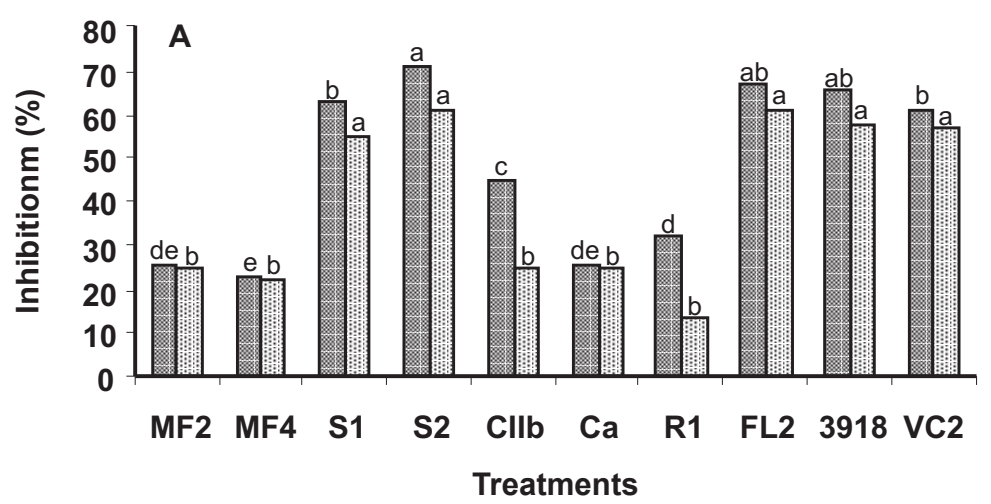

圆PDA Medium 国 MB1 Medium

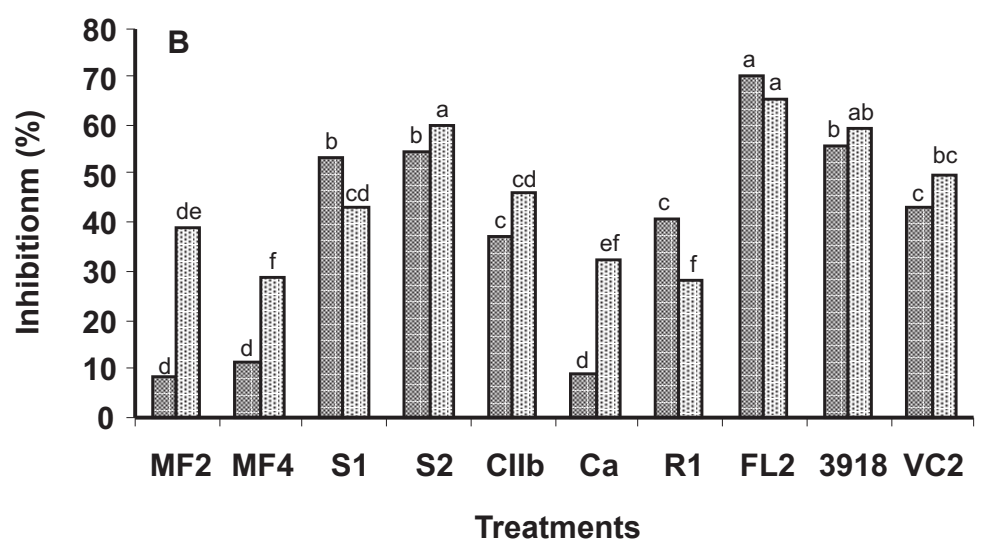

FIGURE 1 - Inhibition of mycelial growth of Cylindrocladium candelabrum A. and of Rhizoctonia solani B. in PDA and MB1 culture media, mediated by rhizobacteria isolates in relation to the control treatment (sterile saline solution). Inhibition values in columns with the same letter for a given culture medium did not differ significantly by Tukey test $(\mathrm{p}<0.5)$. among treatments for $R$. solani during most of the period of incubation. However, for $C$. candelabrum, differences were found among treatments in the time needed for inoculum density to decrease and reach a low level at which it stabilized for the remainder of the incubation period. Inoculum concentration of the pathogen was higher in treated medium than in the control medium beginning at 10 days of incubation. Among the rhizobacteria treatments, isolate $\mathrm{Ca}$ exhibited the highest suppression of pathogen density. At 30 days, the difference between the inoculum of the pathogen in the Ca treated substrate in relation to the control was of $26.7 \%$ (Figure $3 \mathrm{~A}$ ).

A wide variation in fungicide sensitivity was observed in response to the active ingredients tested (Table 1). Tebuconazole inhibited $80 \%$ of isolates and the mixture of epoxyconazole and pyraclostrobin inhibited only growth of S1 isolate. S1 was more sensitive than the other isolates to the tested active ingredients and isolates 3918 and MF2 were the least sensitive. Sensitivity varied among isolates of B. subtilis, Thus, isolates $\mathrm{S} 1, \mathrm{~S} 2$ and 3918 of B. subtilis differed markedly in sensitivity, especially S1 and 3918, which were the most and the least affected, respectively.

\section{DISCUSSION}

This work identified isolates of plant growthpromoting rhizobacteria with potential for the biological control of mini-cutting rot of eucalyptus. These microorganisms are of particular interest because they increased rooting of cuttings, growth of the rooted eucalyptus plants, and protected the cuttings and plants against pathogens. However, in many instances, rhizobacterial isolates have a narrower spectrum of action compared to synthetic pesticides (Baker, 1991; Janisiewicz, 1996). Thus, for use in eucalyptus nurseries it would be preferable to employ biological control agents that are insensitive to the fungicides normally used in the nurseries. The low sensitivity of the rhizobacteria isolates to most fungicides tested in the present work raises the possibility of integrating biocontrol and fungicide use for protecting 

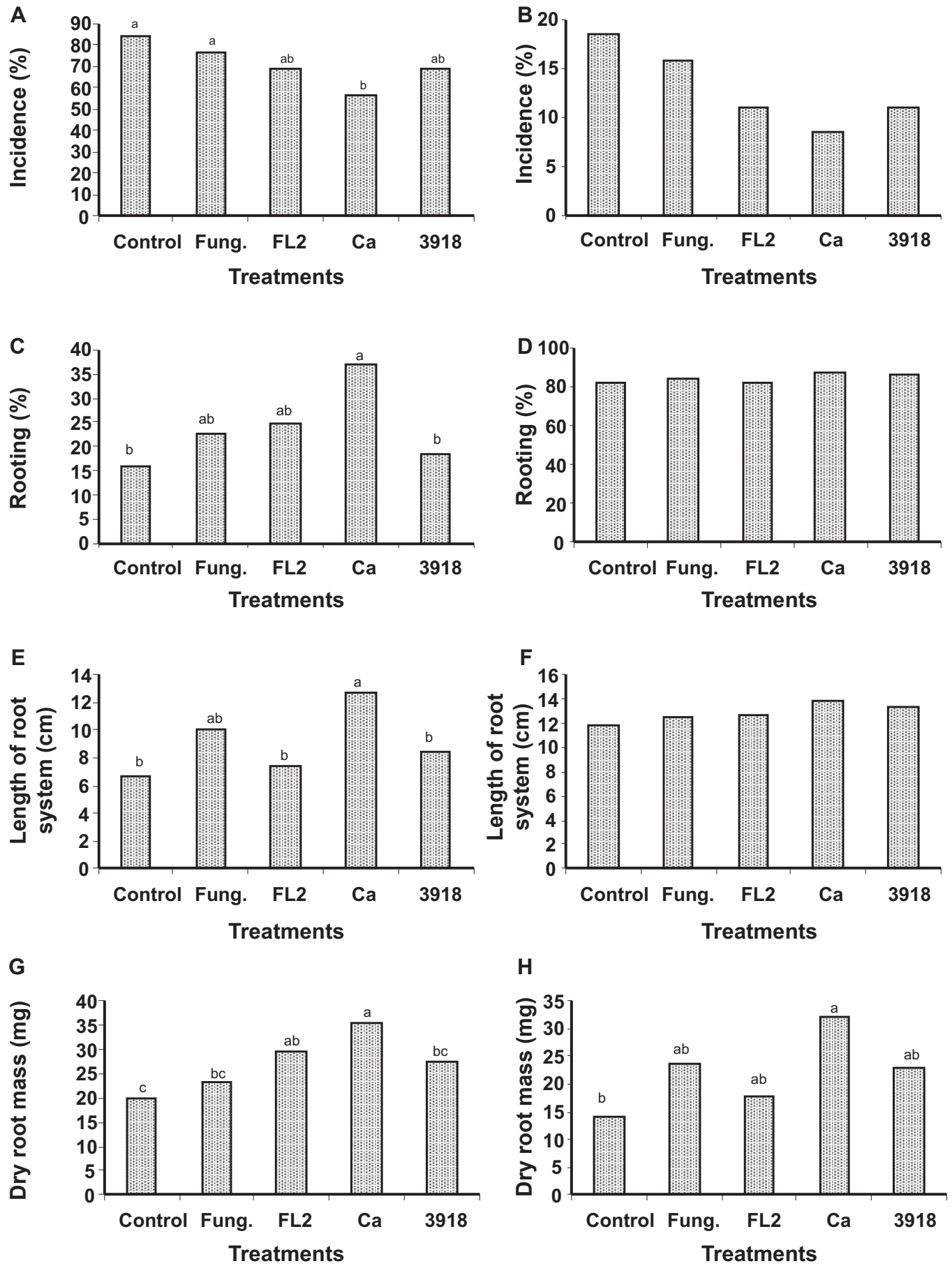

FIGURE 2 - Incidence of mini-cutting rot (A-B), rooting rate (C-D), length of root system (E-F) and biomass of dried roots $(\mathrm{G}$ and $\mathrm{H})$ of eucalyptus mini-cuttings in rooting medium amended with rhizobacteria isolates and infested with Cylindrocladium candelabrum (A, C, E-G) or Rhizoctonia solani (B, D, F-H). Control and fungicide (Fung.) refer to medium infested only with the pathogen and to previous immersion of the mini-cutting in a fungicide mixture, respectively. Columns with the same letter did not differ significantly by Tukey test $(\mathrm{p}<0.5)$.

eucalyptus transplants.

The increased rooting and plant growth obtained with isolate Ca may contribute indirectly to the control of mini-cutting rot caused by $C$. candelabrum. In previous studies we demonstrated that isolate Ca was able to directly affect eucalyptus rooting and growth when applied to the substrate in the absence of plant pathogens (Mafia et al., 2005; Teixeira et al., 2007). Multiple modes of action 


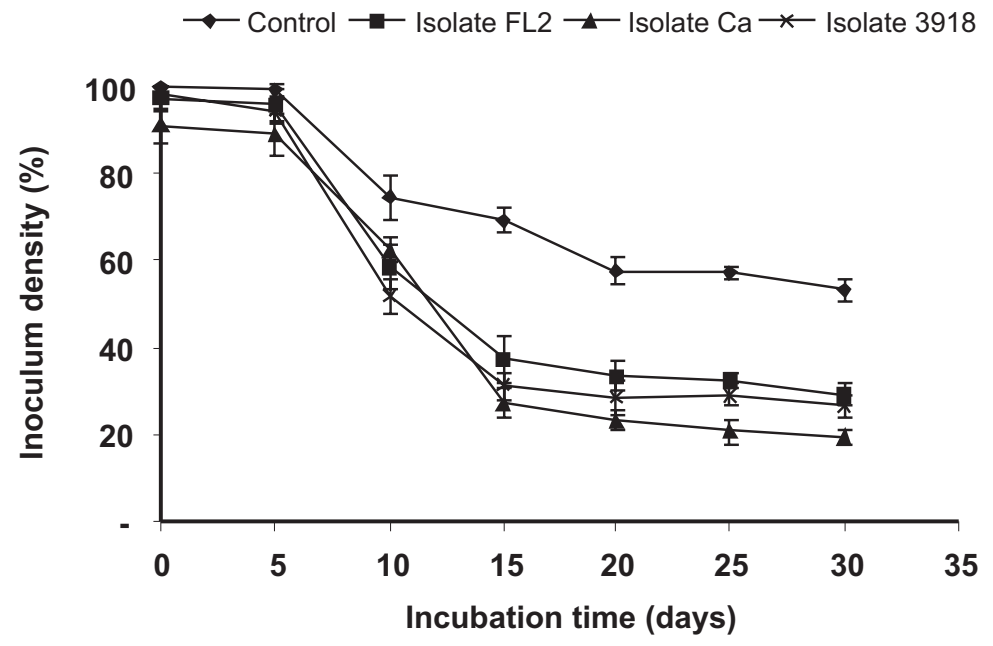

$\rightarrow$ Control $\rightarrow$ Isolate FL2 $\longrightarrow$ Isolate Ca $\rightarrow$ Isolate 3918

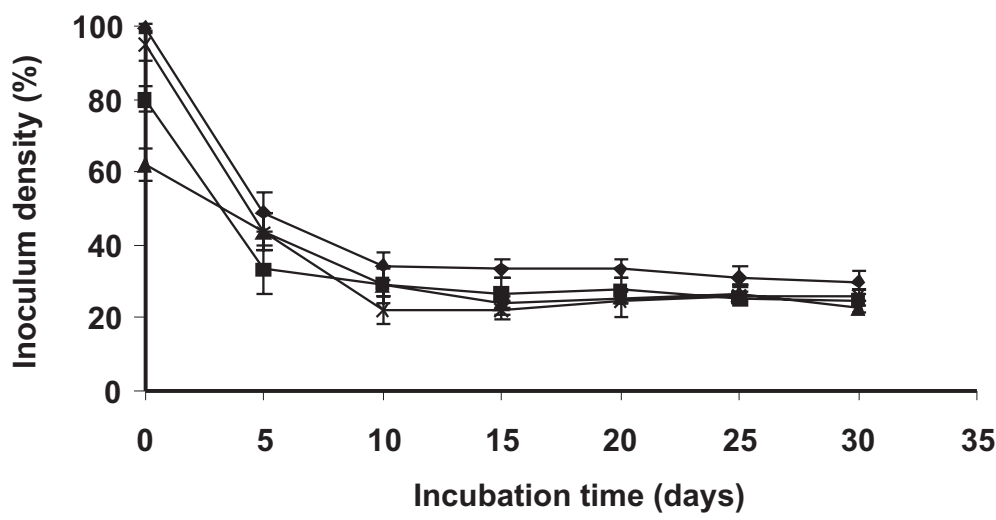

FIGURE 3 - Density of Cylindrocladium candelabrum A. and Rhizoctonia solani B. in rooting medium amended with various rhizobacteria isolates as function of incubation time. The control refers to rooting medium infested only with the pathogen. Bars on data points represent standard deviation.

TABLE 1 - Sensitivity* to various fungicides of rhizobacteria isolates

\begin{tabular}{llllllllllll}
\hline \hline \multirow{2}{*}{ Fungicides (a.i.) } & \multicolumn{10}{c}{ Rhizobacteria Isolates } \\
\cline { 2 - 8 } & & $\mathbf{3 9 1 8}$ & Ca & CIIb & FL2 & MF2 & MF4 & R1 & S1 & S2 & VC2 \\
\hline Azoxystrobin & - & - & + & - & + & - & - & +++ & + & + \\
Captan & - & - & ++ & - & - & + & - & - & - & - \\
Epoxyconazole & - & - & + & - & - & - & + & + & + & - \\
Epoxyconazole + pyraclostrobin & - & - & - & - & - & - & - & + & - & - \\
Iprodione & - & + & + & + & - & - & ++ & + & - & + \\
PCNB & - & + & + & +++ & - & - & - & - & - & - \\
Tebuconazole & + & ++ & + & - & - & ++ & +++ & +++ & +++ & + \\
Tetraconazole & - & - & + & - & - & - & +++ & +++ & - & - \\
Thiram & + & ++ & - & - & - & - & - & + & - & - \\
Triadimenol & - & - & - & - & + & - & + & ++ & - & - \\
Control & - & - & - & - & - & - & - & - & - & - \\
\hline
\end{tabular}

*Inhibition of bacterial growth was estimated according to the diameter of the inhibitory strip as negative (-) when no apparent inhibition occurred; positive $(+)$ when it was less than $1 \mathrm{~mm}$; double positive $(++)$ when equal to or between 1 and $2 \mathrm{~mm}$ and triple positive $(+++)$ when over $2 \mathrm{~mm}$. 
have been reported for numerous strains of rhizobacteria (Bloemberg \& Lugtenberg, 2001).

Several studies have demonstrated the efficiency of rhizobacteria in promoting plant growth under controlled conditions and in the absence of competition from other soil-borne microbes (Cattelan et al., 1999; Weller, 2007). The experimental conditions of the present work, including the moisture content, $\mathrm{pH}$, nutrient content, and microbial composition of the rooting substrate, and several other factors, were similar to conditions used for commercial production of eucalyptus cuttings and thereby minimized representational error. Promotion of plant growth by rhizobacteria in unsterilized soil has often been attributed solely to control of plant pathogenic fungi (Scher \& Baker, 1982; Fridlender et al., 1993; Kloepper \& Schroth, 1981). Reported modes of biocontrol include competition for nutrients, exclusion of pathogens in ecological niches, production of toxic metabolites in direct antibiosis (Kloepper, 1991; Luz, 1993; Whipps, 2001), and induction of systemic resistance (Kloepper et al., 1992; Van Loon, 1997; Van Loon et al., 1998; Ramamoorthy et al., 2001; Eneback \& Carey, 2000; Viswanathan \& Samiyappan, 2002). In the current work we showed that it is possible to use plant growth-promoting rhizobacteria to help optimize cutting production of eucalyptus, for example by the addition of isolate $\mathrm{Ca}$ to the rooting substrate to reduce the incidence of mini-cutting rot. This reduction in rot severity was probably related in part to the observed suppression of pathogen density in the rooting medium. Amendment of the medium with isolate $\mathrm{Ca}$ is a potentially efficient means to make the medium suppressive to the pathogen. Scher \& Baker (1982) demonstrated that application of Pseudomonas putida, a known siderophore producer, made a soil suppressive to Fusarium spp. that attack flax, radish and cucumber. Isolate $\mathrm{Ca}$, the most effective rhizobacterium in the present work, is a strain of P. fulva (Teixeira et al., 2007). Various species of Pseudomonas have been reported to promote plant growth and suppress disease in plants, but because of the difficulties in their formulation they are still used only on a small scale (Buchenauer, 1998).

Antibiotic production was found to correlate with biocontrol efficiency in some instances but not in others (Fenton et al., 1992; Shanahan et al., 1992, Buchenauer, 1998). In the present work it was observed that the isolate (FL2) that was most effective in inhibiting "in vitro" mycelial growth of $C$. candelabrum and $R$. solani was not effective in controlling cutting rot under nursery conditions. In contrast, isolate $\mathrm{Ca}$, which was not effective in antibiosis tests, was the most effective in suppressing of C. candelabrum in the rooting substrate. We consider that other factors such as capacity for survival are also involved. Normally, amendment of the medium with rhizobacteria is carried out only once, which means that to be effective the bacterial inoculum has to establish population densities on the base of the cuttings and in the rhizosphere that are sufficiently high to promote rooting and growth of the cuttings and control disease. Survival and growth of the bacteria, however, depend on available energy sources such as in root exudates of the host plants. Unsatisfactory results for biocontrol by rhizobacteria under field conditions have in some instances been correlated with a low capacity for root colonization (Bloemberg \& Lugtenberger, 2001). The density of the rhizobacteria inoculum used in the present study was efficient in protecting eucalyptus mini-cuttings against the plant pathogenic fungi tested. However, to optimize the commercial use of a rhizobacteria-based bio-product it will be important to estimate the minimum effective inoculum concentration.

Factors that may contribute to inconsistent results in biocontrol tests include the complex interaction between host plants, pathogen, antagonist and environment, such as the low ecological competence and variations in the introduced micro-organism's capacity to colonize roots, absence of the target pathogen or interference of non-target pathogens. To improve the efficiency of biological control, it will be important to develop high quality formulations of the biocontrol agent that have adequate stability and shelf life, effective protocols for using the products in crops, and practical means to estimate inoculum levels of the target pathogen in the crop (Buchenauer, 1998). Our results suggest that at least one of the tested rhizobacteria isolates is efficient in biological control of the C. candelabrum and $R$. solani, by direct antibiosis. Because the tested isolates were not affected by most fungicides tested, their use in crops for biocontrol should prove compatible with chemical control.

\section{REFERENCES}

Alfenas AC, Zauza EAV, Mafia RG, Assis TF (2004) Clonagem e doenças do eucalipto. Viçosa MG. Editora UFV.

Baker R (1991) Diversity in biological control. Crop Protection 10:85-94.

Bloemberg GV, Lugtenberg BJJ (2001) Molecular basis of plant growth promotion and biocontrol by rhizobacteria. Current Opinion in Plant Biology 4:343-350.

Buchenauer H (1998) Biological control of soil-borne diseases by rhizobacteria. Journal of Plant Disease and Protection 105:329348.

Cattelan AJ, Hartel PG, Fuhrmann JJ (1999) Screening for plant growth-promoting rhizobacteria to promote early soybean growth. Soil Science Society of America Journal 63:1670-1680.

Chanway CP (1997) Inoculation of tree roots with PGPR soil bacteria: an emerging technology for reforestation. Forest Science 43:99-112.

Chanway CP, Holl FB (1993a) First year field performance of spruce seedlings inoculated with plant growth promoting rhizobacteria. Canadian Journal of Microbiology 39:1084-1088. 
Plant growth promoting rhizobacteria as agents in the biocontrol...

Chanway CP, Holl FB (1993b) Ecotypic specificity of spruce emergence-stimulating Pseudomonas putida. Forest Science 39:520-527.

Chanway CP, Holl FB (1994) Growth of outplanted lodgepole pine seedlings one year after inoculation with growth promoting rhizobacteria. Forest Science 40:238-246.

Eneback SA, Wei G, Kloepper JW (1998) Effects of PGPR on loblolly and slash pine seedlings. Forest Science 44:139-144.

Eneback SA, Carey WA (200) Evidence for induced systemic protection to fusiform rust in loblolly pine by plant growthpromoting rhizobacteria. Plant Disease 84:306-308.

Fenton AM, Stephans PM, Crowley J, O'Callaghan M, Gara FO (1992) Exploitation of gene(s) involved in 2,4diacetylphloroglucinol biosynthesis to confer a new biocontrol capacity to Pseudomonas strains. Applied and Environmental Microbiology 58:3873-3878.

Fridlender MJ, Inbar J, Chet I (1993) Biological control of soil-borne plant pathogens by a $\beta-1,3$ glucanase-producing Pseudomonas cepacia. Soil Biology and Biochemistry 25:12111221.

Gonçalves RC, Alfenas AC, Maffia LA, Crous PW (2001) Evaluation of bioassays to quantify Cylindrocladium inocula in soil. Mycoscience 42:261-264.

Holl FB, Chanway CP (1992) Rhizosphere colonization and seedling growth promotion of lodgepole pine by Bacillus polymyxa. Canadian Journal of Microbiology 38:303-308.

Janisiewicz WJ (1996) Ecological diversity, niche overlap, and coexistence of antagonists used in developing mixtures for biocontrol of post-harvest diseases of apples. Phytopathology 86:473-479.

Kado EI, Heskett MG (1970) Selective media for isolation of Agrobacterium, Corynebacterium, Erwinia, Pseudomonas and Xanthomonas. Phytopathology 60:969-976.

Kloepper JW, Schroth MN (1981) Relationship of in vitro antibiosis of plant growth-promoting rhizobacteria to plant growth and the displacement of root microflora. Phytopathology 71:1020-1024.

Kloepper JW (1991) Development of in vivo assays for prescreening antagonists of Rhizoctonia solani on cotton. Phytopathology 81:1006-1013.

Kloepper JW, Lifshitz R, Zablotowicz R (1989) Free-living bacterial inocula for enhancing crop productivity. Trends in Biotechnology 7:39-44.

Kloepper JW, Tuzun S, Kuc JA (1992) Proposed definitions related to induced disease resistance. Biocontrol Science and Technology 2:349-351.

Luz WC (1993) Microbiolização de sementes para o controle de doenças de plantas. Revisão Anual de Patologia de Plantas 1:3377 .
Mafia RG, Alfenas AC, Ferreira EM, Zarpelon TG, Siqueira L (2005) Crescimento de mudas e produtividade de minijardins clonais de eucalipto tratados com rizobactérias selecionadas. Revista Árvore 29:843-851.

Ramamoorthy V, Viswanathan R, Raguchander T, Prakasam V, Samiyappan R (2001) Induction of systemic resistance by plant growth promoting rhizobacteria in crop plants against pests and diseases. Crop Protection 20:1-11.

Raupach GS, Kloepper JW (1998) Mixtures of plant growthpromoting rhizobacteria enhance biological control of multiple cucumber pathogens. Phytopathology 88:1158-1164.

Sanfuentes E, Alfenas AC, Maffia LA, Silveira SF (2002) Comparison of baits to quantify inoculum density of Rhizoctonia spp. in Eucalyptus clonal garden soils. Australasian Plant Pathology 31:177-183.

Scher FM, Baker R (1982) Effect of Pseudomonas putida and a synthetic iron chelator on induction of soil suppressiveness to Fusarium wilt pathogens. Phytopathology 72:1567-1573.

Shanahan P, O'Sullivan DJ, Simpson P, Glennon JD, O'Gara F (1992) Isolation of 2,4-diacetylphloroglucinol from a fluorescent pseudomonad and investigations of physiological parameters influencing its production. Applied and Environmental Microbiology 58:353-358.

Shishido M, Chanway CP (2000) Colonization and growth promotion of outplanted spruce seedlings pre-inoculated with plant growth-promoting rhizobacteria in the greenhouse. Canadian Journal of Forest Research 30:845-854.

Silveira SF, Alfenas AC, Maffia LA, Suzuki MS (2003) Controle químico da queima de folhas e da mela de estacas de eucalipto, causadas por Rhizoctonia spp. Fitopatologia Brasileira 28:642649.

Teixeira DA, Alfenas AC, Mafia RG, Ferreira EM, Siqueira LA, Maffia LA, Mounteer AH (2007) Rhizobacterial promotion of eucalypt rooting and growth. Brazilian Journal of Microbiology 38:118-123.

van Loon LC (1997) Induced resistance in plants and the role of pathogenesis-related proteins. European Journal of Plant Pathology 103:753-765.

van Loon LC, Bakker PAHM, Pieterse CMJ (1998) Systemic resistance induce by rhizosphere bacteria. Annual Review of Phytopathology 36:453-483.

Viswanathan R, Samiyappan R (2002) Induced systemic resistance by fluorescent pseudomonads against red rot disease of sugarcane caused by Colletotrichum falcatum. Crop Protection 21:1-10.

Weller DM (2007) Pseudomonas biocontrol agents of soil-borne pathogens: looking back over 30 years. Phytopathology 97:250256.

Whipps JM (2001) Microbial interactions and biocontrol in the rhizosphere. Journal of Experimental Botany 52:487-511. 